\title{
Role of monoclonal antibodies in the treatment of asthma
}

\author{
Paul M O’Byrne MB
}

\author{
PM O'Byrne. Role of monoclonal antibodies in the treatment of \\ asthma. Can Respir J 2013;20(1):23-25.
}

BACKGROUND: Patients with severe refractory asthma represent a small subset of the asthmatic population (between $5 \%$ and $10 \%$ of all patients) but are the greatest burden to the health care system. New treatment approaches developed to manage some of the phenotypes of severe refractory asthma have included humanized monoclonal antibodies (hMabs).

OBJECTIVE: To review the evidence and ascertain whether hMabs provide clinical benefit to patients with severe refractory asthma.

METHODS: Studies that examined the efficacy of hMabs against immunoglobulin (Ig) E, tumour necrosis factor-alpha, interleukin (IL)-5, and IL-4/ IL-13 in patients with severe refractory asthma were reviewed and summarized.

RESULTS: Treatment with anti-IgE improved asthma control and reduced severe exacerbations in patients with severe asthma and elevated serum IgE levels. Treatments with hMabs that block tumour necrosis factoralpha are unlikely to be useful in asthma treatment. In contrast, hMabs that block IL-5 have consistently shown benefit in reducing severe exacerbations in patients with severe refractory asthma with persistent eosinophilia. Finally, hMabs that block IL-13 may provide benefit in patients with elevated blood periostin levels.

DISCUSSION: hMabs that block IgE are approved for the treatment of allergic asthma. It is likely that blocking IL-5 will also provide benefit in patients with severe asthma with persistent eosinophilia. These studies have emphasized the importance of careful phenotyping of patients with severe refractory asthma before embarking on treatment with hMabs.

Key Words: Interleukin-5; Interleukin-13; Severe asthma espite the availability of very effective and safe medications to treat asthma (1), surveys of asthma patient populations indicate that the majority of patients are not fully controlled (2). This lack of asthma control may be due to a variety of factors, including poor adherence to treatment (the most common cause), psychosocial factors, vocal cord dysfunction, persistent exposure to allergens or toxic substances, or undertreated comorbidities. However, a proportion of these patients can be considered to have severe refractory asthma (3).

Patients with severe refractory asthma represent a small subset of the asthmatic population (between $5 \%$ and $10 \%$ of all patients) but are the greatest burden to the health care system in Canada (4) and elsewhere, and are the patient population most in need of new treatment approaches. Efforts have been undertaken to phenotype patients with severe refractory asthma, which have included unbiased cluster analyses (5) and phenotyping based on the type of airway inflammatory cells (6). It has, however, become clear that no single phenotype can explain all severe refractory asthma and no single treatment approach will improve asthma control in all patients with severe disease.

New treatment approaches developed to manage some of the phenotypes of severe refractory asthma have included humanized monoclonal antibodies (hMabs) against immunoglobulin (Ig) E, or specific cytokines known to be important in the initiation or

\section{Le rôle des anticorps monoclonaux dans le traitement de l'asthme}

HISTORIQUE : Les patients atteints d'un asthme réfractaire grave constituent un petit sous-ensemble de la population asthmatique (de $5 \%$ à $10 \%$ de tous les patients), mais représentent le plus grand fardeau pour le système de santé. De nouvelles démarches thérapeutiques mises au point pour prendre en charge certains des phénotypes de l'asthme réfractaire grave incluent des anticorps monoclonaux humanisés (acMh).

OBJECTIFS : Examiner les données probantes et évaluer si les acMh procurent des bienfaits cliniques aux patients ayant un asthme réfractaire chronique.

MÉTHODOLOGIE : Les chercheurs ont examiné et résumé des études sur l'efficacité des acMh contre l'immunoglobuline (Ig) E, le facteur de nécrose tumorale alpha, l'interleukine (IL)-5 et l'IL-4/IL-13 chez des patients ayant un asthme réfractaire grave.

RÉSULTATS : Le traitement à l'anti-IgE améliorait le contrôle de l'asthme et en réduisait les graves exacerbations chez les patients ayant un asthme grave et un taux élevé de sérum IgE. Les traitements comportant des acMh qui bloquent le facteur de nécrose tumorale sont peu susceptibles d'être utiles en présence d'asthme. Par contre, les acMh qui bloquent l'IL-5 contribuent toujours à réduire les exacerbations graves chez les patients ayant un asthme réfractaire grave accompagné d'une éosinophilie persistante. Enfin, les acMh qui bloquent l'IL-13 peuvent être bénéfiques pour les patients ayant un taux de périostin sanguin élevé.

EXPOSÉ : Les acMh qui bloquent l'IgE sont approuvés dans le traitement de l'asthme allergique. Il est probable que l'IL-5 profitera également aux patients ayant un asthme grave accompagné d'éosinophilie persistante. Ces études font ressortir l'importance d'établir soigneusement le phénotype des patients ayant un asthme réfractaire grave avant d'entreprendre un traitement aux acMh.

persistence of asthmatic inflammation. A large number of hMabs have been evaluated in preclinical models of allergic asthma. The present article reviews selected studies that have evaluated the efficacy of hMabs in severe refractory asthma.

\section{ANTI-IgE hMAB}

An hMab that blocked binding of IgE to its receptor (FceR1) (omalizumab) was the initial hMab to demonstrate efficacy in asthma and is now recommended in asthma guidelines as a treatment option for patients with severe refractory asthma (1). Several studies have demonstrated that omalizumab improves asthma control and reduces severe exacerbations in both adults (7) and children (8) with severe disease and elevated serum IgE levels. Interestingly, the benefit demonstrated in children was predominantly apparent during the autumn asthma exacerbation peak.

\section{ANTITUMOUR NECROSIS FACTOR-ALPHA hMABs}

The management of several chronic inflammatory diseases, such as rheumatoid arthritis and inflammatory bowel disease, has been revolutionized by the availability of hMabs that block the action of tumour necrosis factor-alpha (TNF- $\alpha$ ). Early studies in asthma involving selected patients with elevated TNF- $\alpha$ levels in bronchoalveolar lavage fluid or an increased expression of membrane-bound 

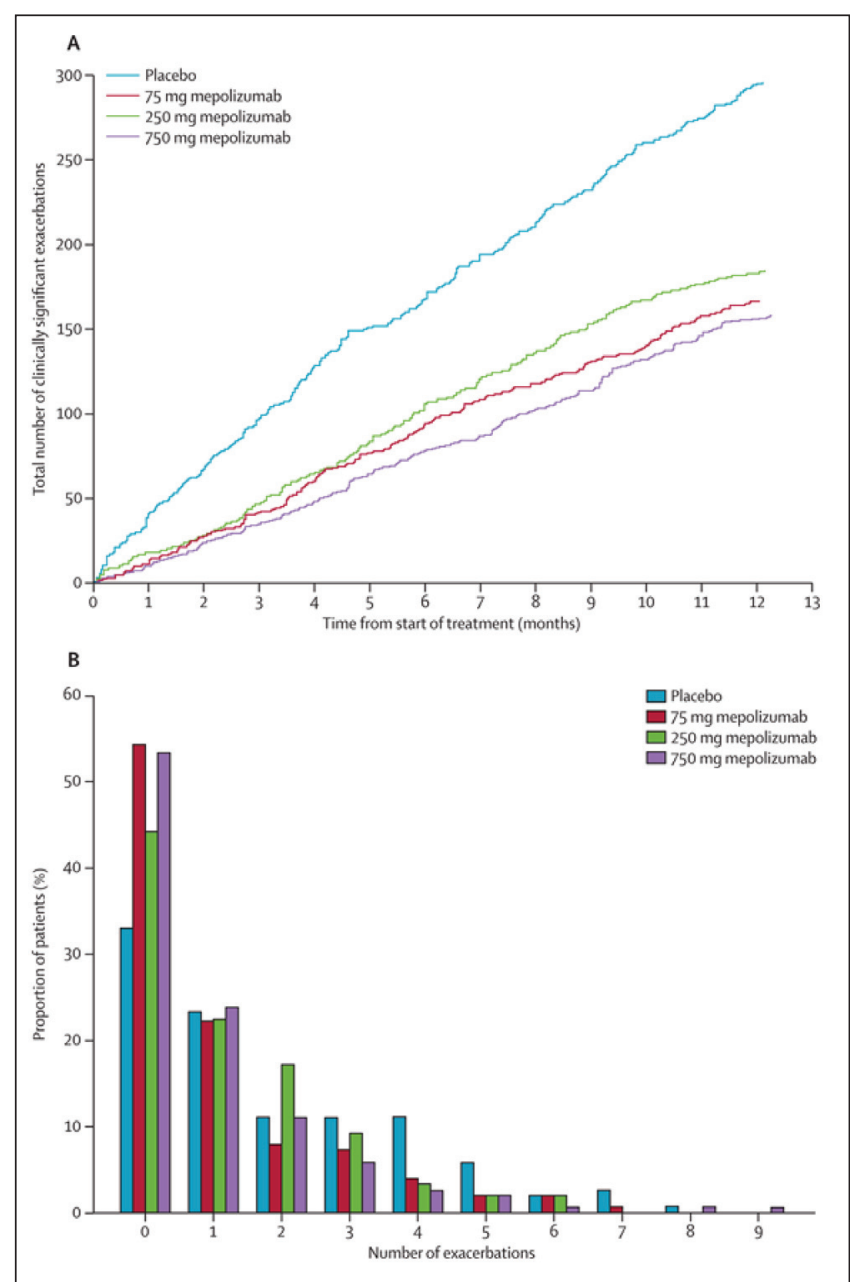

Figure 1) Number of severe asthma exacerbations in patients treated with mepomalizumab $75 \mathrm{mg}, 250 \mathrm{mg}$ or $750 \mathrm{mg}$ or placebo for one year. A Cumulative number of asthma exacerbations with time. B Distribution of number of asthma exacerbations. Reproduced with permission from reference 17

TNF- $\alpha$ demonstrated an improvement in asthma control and airway hyper-responsiveness $(9,10)$. However, larger clinical trials involving patients with severe refractory asthma, but not elevated TNF- $\alpha$ levels in the airways, did not confirm these benefits $(11,12)$ and, in one study (11), was associated with an increased number of adverse effects including malignancy. It is, therefore, unlikely that anti-TNF- $\alpha$ treatment approaches will be used for asthma treatment.

\section{ANTI-INTERLEUKIN-5 hMABs}

The biological activity of interleukin (IL) -5 is specifically focused on the development, differentiation, recruitment, activation and survival of eosinophils. Approximately 50\% of severe asthma exacerbations are eosinophilic in nature, and studies have demonstrated that asthma treatment decisions based on minimizing airway eosinophil levels (measured in induced sputum) can reduce the risks of severe exacerbations (13). Two hMabs that bind IL-5 and prevent its interaction with its receptor (mepolizumab and reslizumab) have been developed. When these antibodies were evaluated in patients with severe refractory asthma, but who were not selected on the basis of a persisting airway eosinophilia, no clinical benefit could be demonstrated (14). However, treatment of patients with severe refractory asthma with persisting airway eosinophilia and who were dependent on oral corticosteroids to minimize airway eosinophilia with mepolizumab resulted in a reduction in the number of blood and airway eosinophils to within the normal range. Furthermore, treatment enabled a reduction of oral corticosteroids, reduced the number of severe asthma exacerbations, improved forced expiratory volume in $1 \mathrm{~s}\left(\mathrm{FEV}_{1}\right)$ and measures of asthma control (15). This benefit of mepolizumab has also been shown in asthmatic patients with refractory asthma, but not requiring oral corticosteroids to manage their airway eosinophilia (16) and in a larger study involving selected patients with increased blood eosinophil levels (17) (Figure 1). Subsequently, treatment with reslizumab has demonstrated benefits in improving $\mathrm{FEV}_{1}$ and asthma control, again in patients with severe refractory asthma and persisting airway eosinophilia (18). A third hMab against IL-5 (benzalizumab), which binds to the IL-5 receptor, is also in clinical trials involving patients with severe asthma. The magnitude of benefit in reducing severe asthma exacerbations that these hMabs have consistently demonstrated in patients with severe refractory asthma and persisting airway eosinophilia, make it very likely that they will be a useful therapeutic option for patients of this specific phenotype.

\section{ANTI-IL-4/IL-13 hMABs}

Both IL-4 and IL-13 are important cytokines in the initiation and persistence of allergic airway inflammation. They have been demonstrated to be necessary for IgE production, mucous gland hyperplasia, eosinophilic airway inflammation and airway hyper-responsiveness. These cytokines act through receptors that share a common alphachain (IL-4R $\alpha$ ), which can bind either IL-4 or IL-13. Several approaches have been used to block the activation of these receptors. One approach has been to develop an IL-4 variant - a 'mutene' molecule - that inhibits binding of IL-4 and IL-13 to IL-4R $\alpha$. This molecule has been shown to attenuate allergen-induced late asthmatic responses in subjects with asthma (19). In addition, hMabs that prevent binding of IL-4 or IL-13 to their receptors have also been developed. One study involving allergic asthmatic subjects (20) has shown that an hMab that prevents binding of IL-13 to IL-4R $\alpha$, but not an hMab that prevents binding of IL-13 to IL-13R $\alpha 1$ (the remaining component of the IL-13 receptor) or IL-13R $\alpha 2$ (which may be a natural antagonist of IL-13), also attenuates allergen-induced early and late asthmatic responses, but not allergen-induced eosinophilic airway inflammation nor airway hyper-responsiveness.

Studies involving patients with persisting asthma have yielded interesting results. In one study, treatment with an hMab, which prevents binding of IL-4 and IL-13 to IL-4R $\alpha$, did not demonstrate significant benefit in improving lung function or asthma control, but did show a trend in reducing asthma exacerbations (21). Interestingly, some benefit was apparent in patients with the most poorly controlled asthma. Another study, involving patients with severe refractory asthma (22), reported that an antibody that binds to IL-13 and prevents its attachment to the IL-4/IL-13 receptor complex did not significantly improve $\mathrm{FEV}_{1}$ values in the patient population as a whole but did provide a significant and clinically useful improvement in patients with high blood periostin levels. Periostin, a protein component of subepithelial fibrosis, is released from epithelial cells following stimulation by IL-13 (23). The periostin gene has been identified as being upregulated in epithelial cells of asthma patients (24).

\section{CONCLUSIONS}

The use of hMabs to treat asthma was supported by evidence of the efficacy of omalizumab in patients with allergic asthma and its subsequent approval by drug regulatory agencies worldwide. There is convincing evidence supporting the benefit of anti-IL-5 hMabs in patients with severe refractory asthma and persisting airway eosinophilia, and it is highly likely that these hMabs will be helpful in the management of this phenotype of severe asthma. Treatment approaches to block IL-13 activation of its receptor are also showing promise in patients with an enhanced IL-13 phenotype reflected by high blood periostin levels. Collectively, these studies have emphasized the importance of careful phenotyping of patients with severe refractory asthma before embarking on treatment with hMabs. 


\section{REFERENCES}

1. Lougheed MD, Lemiere C, Ducharme FM, et al. Canadian Thoracic Society 2012 guideline update: Diagnosis and management of asthma in preschoolers, children and adults. Can Respir J 2012;19:127-64.

2. Demoly P, Annunziata K, Gubba E, Adamek L. Repeated crosssectional survey of patient-reported asthma control in Europe in the past 5 years. Eur Respir Rev 2012;21:66-74.

3. Bousquet J, Mantzouranis E, Cruz AA, et al. Uniform definition of asthma severity, control, and exacerbations: Document presented for the World Health Organization Consultation on Severe Asthma. J Allergy Clin Immunol 2010;126:926-38.

4. Bedouch P, Marra CA, FitzGerald JM, Lynd LD, Sadatsafavi M. Trends in asthma-related direct medical costs from 2002 to 2007 in British Columbia, Canada: A population based-cohort study. PLoS One. 2012. (In Press)

5. Haldar P, Pavord ID, Shaw DE, et al. Cluster analysis and clinical asthma phenotypes. Am J Respir Crit Care Med 2008;178:218-24.

6. Wenzel SE, Schwartz LB, Langmack EL, et al. Evidence that severe asthma can be divided pathologically into two inflammatory subtypes with distinct physiologic and clinical characteristics. Am J Respir Crit Care Med 1999;160:1001-8.

7. Hanania NA, Alpan O, Hamilos DL, et al. Omalizumab in severe allergic asthma inadequately controlled with standard therapy: A randomized trial. Ann Intern Med 2011;154:573-82.

8. Busse WW, Morgan WJ, Gergen PJ, et al. Randomized trial of omalizumab (anti-IgE) for asthma in inner-city children. N Engl J Med 2011;364:1005-15.

9. Howarth PH, Babu KS, Arshad HS, et al. Tumour necrosis factor (TNFalpha) as a novel therapeutic target in symptomatic corticosteroid dependent asthma. Thorax 2005;60:1012-18.

10. Berry MA, Hargadon B, Shelley M, et al. Evidence of a role of tumor necrosis factor alpha in refractory asthma. N Engl J Med 2006;354:697-708.

11. Wenzel SE, Barnes PJ, Bleecker ER, et al. A randomized, doubleblind, placebo-controlled study of tumor necrosis factor-alpha blockade in severe persistent asthma. Am J Respir Crit Care Med 2009;179:549-58

12. Holgate ST, Noonan M, Chanez P, et al. Efficacy and safety of etanercept in moderate-to-severe asthma: A randomised, controlled trial. Eur Respir J 2011;37:1352-59.
13. Jayaram L, Pizzichini MM, Cook RJ, et al. Determining asthma treatment by monitoring sputum cell counts: Effect on exacerbations. Eur Respir J 2006;27:483-94.

14. Flood-Page P, Swenson C, Faiferman I, et al. A study to evaluate safety and efficacy of mepolizumab in patients with moderate persistent asthma. Am J Respir Crit Care Med 2007;176:1062-71.

15. Nair P, Pizzichini MM, Kjarsgaard M, et al. Mepolizumab for prednisone-dependent asthma with sputum eosinophilia. N Engl J Med 2009;360:985-93.

16. Haldar P, Brightling CE, Hargadon B, et al. Mepolizumab and exacerbations of refractory eosinophilic asthma. $\mathrm{N}$ Engl J Med 2009;360:973-84.

17. Pavord ID, Korn S, Howarth P, et al. Mepolizumab for severe eosinophilic asthma (DREAM): A multicentre, double-blind, placebo-controlled trial. Lancet 2012;380:651-9.

18. Castro M, Mathur S, Hargreave F, et al. Reslizumab for poorly controlled, eosinophilic asthma: A randomized, placebo-controlled study. Am J Respir Crit Care Med 2011;184:1125-32.

19. Wenzel S, Wilbraham D, Fuller R, Getz EB, Longphre M. Effect of an interleukin-4 variant on late phase asthmatic response to allergen challenge in asthmatic patients: Results of two phase $2 \mathrm{a}$ studies. Lancet 2007;370:1422-31.

20. Gauvreau GM, Boulet LP, Cockcroft DW, et al. Effects of interleukin-13 blockade on allergen-induced airway responses in mild atopic asthma. Am J Respir Crit Care Med 2011;183:1007-14.

21. Corren J, Busse W, Meltzer EO, et al. A randomized, controlled, phase 2 study of AMG 317, an IL-4R alpha antagonist, in patients with asthma. Am J Respir Crit Care Med 2010;181:788-96.

22. Corren J, Lemanske RF, Hanania NA, et al. Lebrikizumab treatment in adults with asthma. N Engl J Med 2011;365:1088-98.

23. Takayama G, Arima K, Kanaji T, et al. Periostin: A novel component of subepithelial fibrosis of bronchial asthma downstream of IL-4 and IL-13 signals. J Allergy Clin Immunol 2006;118:98-104.

24. Woodruff PG, Boushey HA, Dolganov GM, et al. Genome-wide profiling identifies epithelial cell genes associated with asthma and with treatment response to corticosteroids. Proc Natl Acad Sci USA 2007;104:15858-63. 


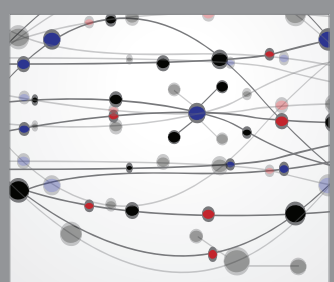

The Scientific World Journal
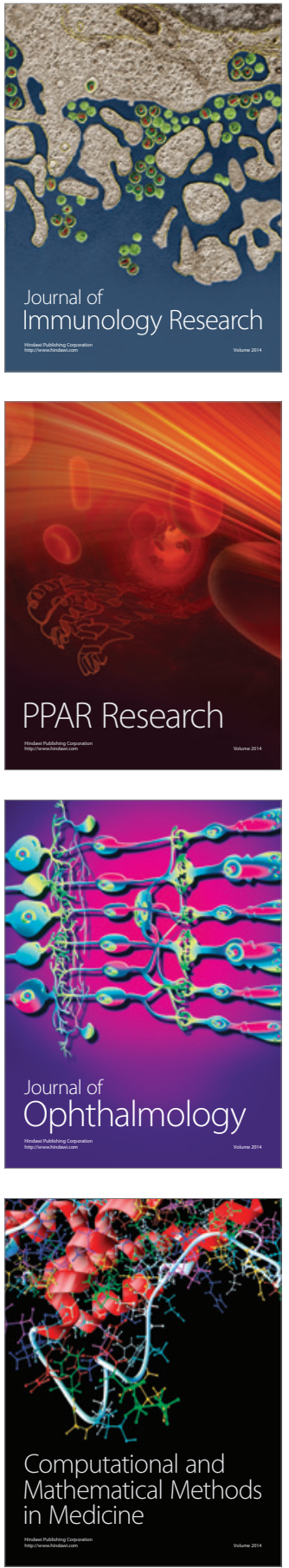

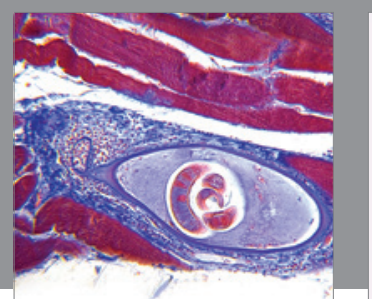

Gastroenterology Research and Practice

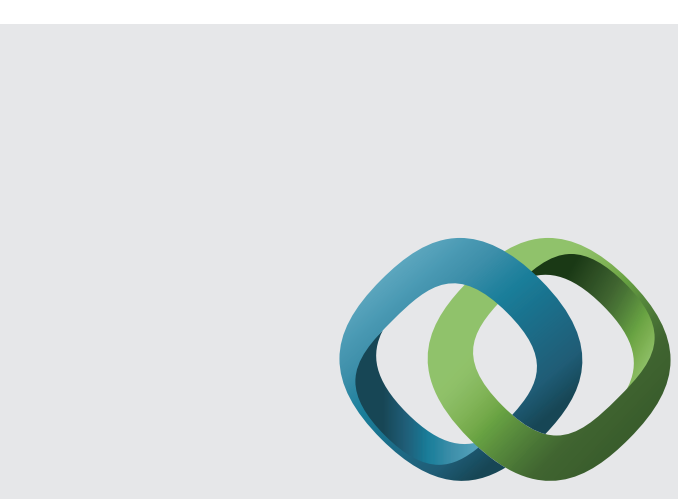

\section{Hindawi}

Submit your manuscripts at

http://www.hindawi.com
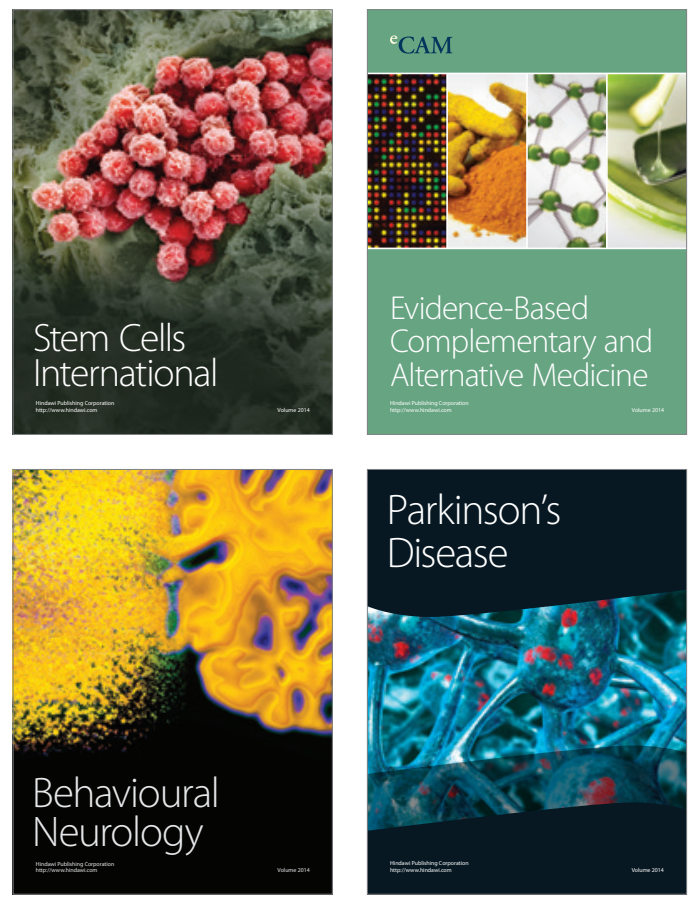
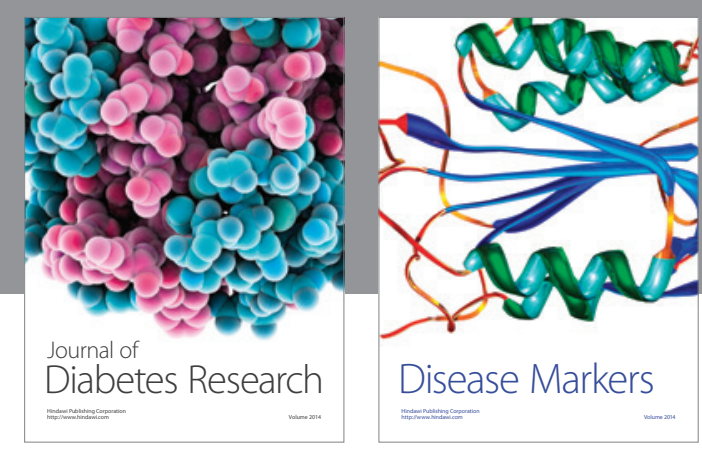

Disease Markers
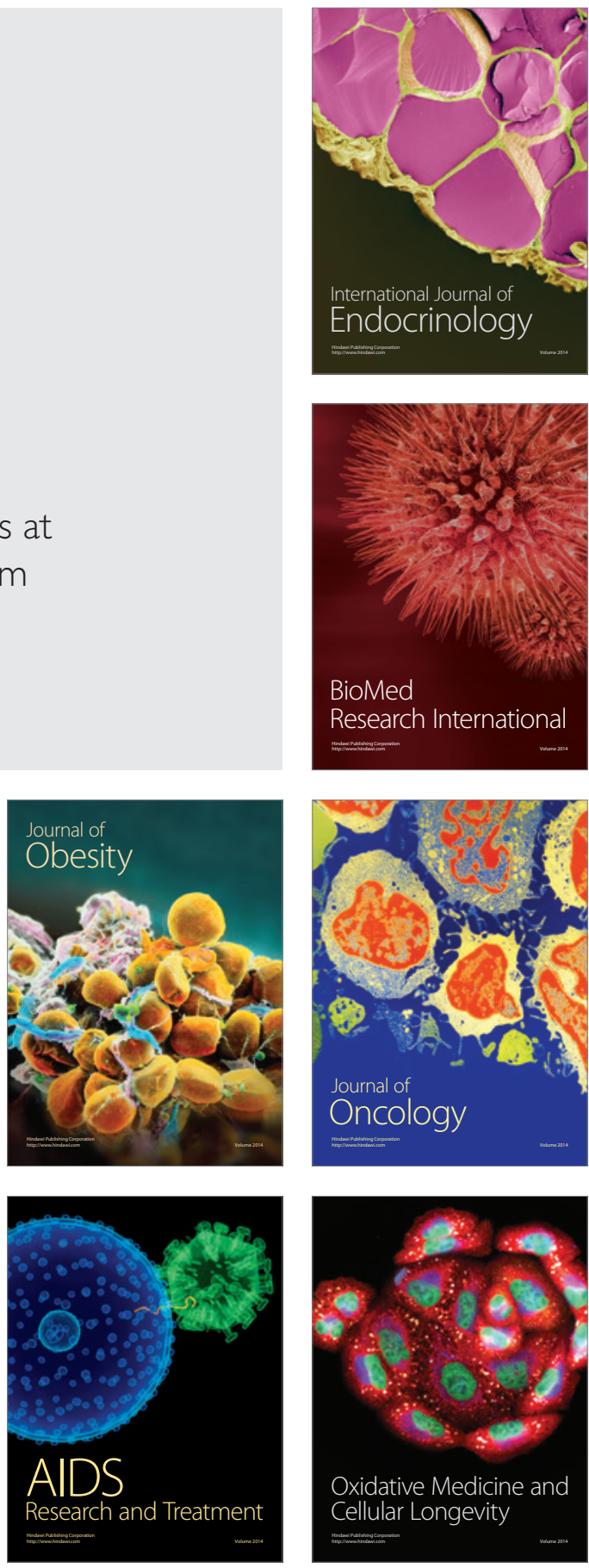